\author{
Andrej Miklosik, \\ Ph.D., Associate Professor, Comenius University in Bratislava, Slovak Republic \\ ORCID ID 0000-0003-3318-534X, \\ email: andrej.miklosik@fm.uniba.sk \\ Peter Starchon, \\ Ph.D., Professor, Comenius University in Bratislava, Slovak Republic \\ (iD) ORCID ID 0000-0002-8806-4150, \\ email: peter.starchon@fm.uniba.sk \\ Dana Vokounova, \\ Ph.D., University of Economics in Bratislava, Slovak Republic \\ email: dana.vokounova@euba.sk \\ Marína Korcokova, \\ Ph.D., University of Economics in Bratislava, Slovak Republic \\ email: marina.korcokova@euba.sk \\ Correspondence author: peter.starchon@fm.uniba.sk
}

\title{
THE FUTURE OF TV ADVERTISING TARGETING YOUNG SLOVAK CONSUMERS
}

Abstract. The consumer preferences and behaviour should be considered with the purpose to implement marketing strategies in today's world successfully. It is crucial to understand how consumers find information and how the consumer decision-making process develops in time. Therefore, for advertisers, considering the behaviour of their target audience is of paramount importance. Integrated marketing communication programs reflect the way online search and traditional and new media, such as smartphones, TV, and social media, influence consumer decision-making. Young consumers, often referred to as generations $Y$ and $Z$, are very different from previous generations in terms of multimedia content consumption and their perception of television advertising. This paper aims at providing insights into this behaviour, including actions that follow-up as a response to television advertising. Results of a quantitative study performed on the sample of 135 university students from Slovakia using a sixcomponent behaviour explanation model. The results reveal that it still can be beneficial to include television advertisements in the communication mix aimed at these young consumers. The investments in TV advertising campaigns could pay off. The advertisers and their agencies should respect the role of high search visibility in this process. In this case, the messages contained in TV advertisements have the potential to influence the purchasing behaviour of young consumers. Thanks to achieving top ranking for the relevant brand, product, and campaignrelated keywords, communication campaigns can become truly integrated. Thus, the component of search visibility directly influences the efficiency of marketing communication, contributing to enhanced business performance. Suggestions towards the optimisation of the delivery of communication campaigns featuring TV advertising should target these consumers are presented based on the generated knowledge about their attitude towards and consumption of TV ads and subsequent behaviours.

Keywords: consumer behaviour, information research, integrated marketing communication, search visibility, television advertising, Slovakia.

Introduction. At the dawn of the 21st century, the holistic concept of marketing seems to be crucial, with its comprehensive and systemic approach. Holistic marketing management is a wide-spectrum phenomenon related to the other significant dimensions, activities, methods, tools, procedures, and technologies of marketing management. To search for product information, people today use several devices simultaneously or subsequently continue searching on another device. Companies need to be

Cite as: Miklosik, A., Starchon, P., Vokounova, D., \& Korcokova M. (2020). The Future of TV Advertising Targeting Young Slovak Consumers Marketing and Management of Innovations, 2, 122-138. http://doi.org/10.21272/mmi.2020.2-09 
aware of the way these processes work and reflect this knowledge in their marketing strategies, including communication campaigns. Thus, integrated marketing communications directly enhance marketing efficiency, and through it, the long-term business performance.

This paper focuses on exploring whether and in what way the young Slovak consumer responds to TV advertising. More detailed knowledge about these responses and other steps enable television advertisers to find out whether it is reasonable for them to focus on young consumers born between 1990 and 1998. These consumers are often referred to as Generations $Y$ and Z. Although some issues have been raised about labelling generations (Searle, 2019), technological skills and nativity to the digital environment are typical for these young consumers. They are entering the workforce, and their purchasing power will continue to increase in the years to come. Understanding their behaviour helps correctly set all communication channels so that a brand/product in a TV advertisement can be considered in the consumer decision-making process.

Literature Review. Consumer behaviour has a transforming character. It is determined by the social formation and vice versa. It is related to the lifestyle changes facilitated by new possibilities of content consumption, communication, and interaction provided by digital media. The technological development and changes in social and societal trends have a far-reaching impact on consumer perception and behaviour. Currently, most consumers are multimedia consumers (Tsai and Lin, 2015). Their television and multimedia consumption patterns have evolved, they are more sophisticated and demanding. Marketing communication needs to adapt to these new trends to reach the target audience and achieve the desired goals and conversions.

The young people are noted for their digital skilfulness. To be digitally competent in today's world, one needs to have not only access to ICT, but also the necessary knowledge, skills, and attitudes related in addition to that. There is a generation of young people who are growing up surrounded by digital technologies and who can intuitively appropriately use such techniques. Relevant literature suggests various labels to refer to the respective generations: Generation $Y-$ Millennials; Generation Z - referred to as the Centennials, digital natives or iGeneration - the Internet generation; and Generation Alpha.

Often referred to as Millennials, Generation Y consists of people born between 1980 and 1995 (or 2000 as there is no strictly defined period). Some studies describe this generation from various aspects, agreeing on some issues, while suggesting different, and even opposing characteristics on others. Individuals belonging to this generation are flexible, focused on their autonomy and fast career growth (Cordeiro and de Albuquerque, 2017). These people are self-confident, optimistic, and capable of attending to several issues at the same time, thanks to their swiftness and vitality (Israfilzade, 2018). They are more focused on hedonistic rather than social values (Dlacic and Kadic-Maglajic, 2013). They are also the first generation ever to be born in a digital era. As such, they are always online (Gewald et al., 2017). Lancaster and Stillman (2009) described Generation $Y$ as a digital generation that lives globally; tries everything for themselves; has cybernetic, media, and technological skills; acknowledges diversity and expects others to do similarly; and is environmentally aware. Gurau (2012) describes Generation $\mathrm{Y}$ as egoistic yet ecologically friendly consumers fascinated by technologies.

For Generation Z, the Internet is the principal medium. Born between 1996 and 2010, Generation Z members are also socially aware, technologically savvy, extraordinarily innovative, and always seeking change. They are permanently online and interconnected via smartphones, tablets, and the Internet of Things. They are very tolerant, enormously self-confident, and confused by violence and adult content in the media. They prefer written forms of communication to oral ones. Finally, they have access to more information than any other generational cohort (Kardes et al., 2014). They are responsive to teaser campaigns and blog marketing. They work with retail applications which they download onto their smartphones. They respond to «word-of-mouth» recommendations by their acquaintances and buzz 
marketing more sensitively than to classical and marketing information. They also very positively respond to guerrilla marketing since they appreciate communication in unusual places and situations. $A$ key factor is to arouse consumers' curiosity.

Generation Alpha is a generation whose members are growing up with iPads in their hands. While not being familiar with the world without smartphones, they will be able to transmit their ideas online within seconds. These massive technological changes mean, among other things, that this generation will be the most transformational and educated ever. Its first members were born in 2010, the year when the first iPad was launched, Instagram was established, and «app» became the word of the year. Growing up as «screenagers», these children are therefore also referred to as Glass Generation.

Particular generation features are commonly observable, also in Slovakia (Olsavsky, 2016; Smolka, 2019). Although the generations described above are noted for their unique characteristics, they have one thing in common, namely, that their consumer behaviour is completely inherent or adjusted to contemporary trends on the digital market. Understanding their common characteristics helps marketers tailor communication messages across various media by integrating offline and online channels through search visibility.

Changes in the area of consumer behaviour are caused, besides other factors, by the constant advancement and development of information technologies. Adopting new technologies represents both opportunities and challenges for organisations (Haviernikova and Kordos, 2019). The availability of an enormous volume of information on the Internet enables young consumers to thoroughly and quickly assess various alternatives and decide in a considerably shorter time than was the case in the past. From the perspective of digitalisation and digital economics, the most critical changes that influence consumer behaviour include the following facts:

1. A significant increase in the availability of user feedback, mainly thanks to social media, which creates a new alternative to information from producers, independent professional testing centres or other reviews (Du et al., 2019; Nadeem et al., 2015).

2. The continuous growth of trust in online shopping (Raman, 2019), whereas the age (belonging to a particular generation) of the consumer has an impact on the level of trust in the published information by either the company or user-generated content (Herrando et al., 2019).

3. The spread of digital mobile devices and a change in the usage of these devices. The «multiscreen» trend, i.e., the parallel or sequential use of multiple devices that become evident in media consumption, information searches, but also shopping, with search results helping navigate between different devices and information search sessions (Google, 2012; Hall et al., 2017; Han et al., 2015; Montanez et al., 2014; Wu et al., 2018).

4. The effort by companies to place their information and products among search results, reflecting the constant changes in search algorithms, enables consumers to find relevant information faster, including reviews, store locations, maps and other content in rich snippets (Miklosik et al., 2019; Okada and de Souza, 2011; Strzelecki, 2019).

Currently, consumers have many options for finding information that helps them decide when buying a product. Providing excellent visibility among search results is essential to make sure that potential consumers have an opportunity to find information about the company and its products (Strzelecki, 2020). Consequently, changes in approaches and satisfaction of customers with provided products, enterprise processes and business strategy (Hitka et al., 2019) that are trying to reflect different consumer preferences and attitudes (Lizbetinova and Weberova, 2016) are apparent. On the Internet, one can find both official information published by companies and user-generated content, including reviews, discussions, and evaluations (Greenberg and Kates, 2013). Besides, numerous studies confirmed the interconnection among consumer interests, product sales, and consumer online search activities (Jepsen, 2007; Jun and Park, 2016; Vosen and Schmidt, 2011). 
These are the facts that point out that marketing strategies, to have the expected impact and be sustainable long-term, need make sure that company products are visible when consumers search for information (Gil-Pechuan et al., 2014). Several search engines could be considered when thinking of search visibility, depending on the location where products are sold. Google is a long-time global leader in the search market, being the number one search engine in most countries. In December 2019, $92.71 \%$ of online searches worldwide were done through Google, followed by Bing $-2.32 \%$, Yahoo! $1.59 \%$, Baidu $-1.06 \%$, and Yandex $-0.5 \%$ (Statcounter, 2020). It is necessary to realise that search visibility is of utmost importance, especially for launching new TV vision communication campaigns that also include other media.

If consumers are interested in a TV, radio spot or a billboard message, there will be a perfect chance that they would like to learn more about the company or the product. Search visibility regarding the keywords related to a TV campaign is, therefore, decisive for achieving a sufficient flow of the information communicated to the consumer and making sure that this information gets through the whole network of traditional and online media (Miklosik, 2014). Thus, advertisers should focus not only on search visibility for a comprehensive set of keywords related to their brand and portfolio but also on attending to the messages and products that are part of their TV spots.

It needs to be recognised that young consumers tend to avoid advertising actively. Therefore, native advertising - a subtle form of digital advertising that is closely related to context, is getting more efficient. Expert practitioners increasingly assign budgets to this advertising strategy (Harms et al., 2017). One of the forms of native advertising is influencer marketing. Posts published by influencers have a higher degree of both engagement and impact than contributions forwarded by the brand itself (Chou, 2018). A product can be integrated into the influencers' regular content which makes their contributions look less product biased. Thus, when non-native advertising forms are incorporated into the communication mix, the behaviour of young consumers who are exposed to the advertising needs to be understood and considered so that the communication message has a chance to go through all the offline and online channels.

Another consideration regards to the way young consumers consume content. According to a TNS survey (Strategie, 2014), Slovak consumers on average own more than four digital devices (e.g., mobile phone, smartphone, tablet, PC, notebook, PlayStation, smart TV). According to eMarketer, users spend an average of two hours and 55 minutes each day using a smartphone (eMarketer, 2019). Because they are online (almost) all the time (Stefko et al., 2019), it's natural for them to multitask and while watching TV, be involved in other digital activities simultaneously. Understanding how millennials perceive media credibility can support the planning and execution of successful media campaigns directed at this vital consumer group (Vilcekova, 2016). This phenomenon is referred to as multi-screening and has been explained by an earlier Google study (Google, 2012). While consumers are watching TV, they are also attending to their smartphone or computer. It is referred to as parallel multi-screening. The sequential mode of using multiple devices is equally essential for merchandisers.

In contrast to the parallel mode, when the user simultaneously focuses on two devices and two screens, in the sequential mode, he or she starts searching for information on one machine just to continue on another device later. It becomes the case especially when searching begins on a mobile device (e.g., while watching TV) and continues on a portable or desktop computer then. Relevant literature has coined the terms "cross-session» and "cross-device search» to define the behaviour of the users who do not finish their search within a single search session (Kotov et al., 2011; Wang et al., 2013; Wu et al., 2018).

According to Nielsen (2015), the current situation can be designated as screen wars - the battle for eye space in the TV-everywhere world. Their report states that, instead of watching TV in a linear model, consumers are now more in control of what we watch, when we watch it and where we watch it. Even 
though these tendencies, TV advertising continues to represent a relevant market and television is widely included in the communication mix of (primarily) more prominent brands. In Slovakia, TV advertising spending has increased between 2016 and 2019 and was expected to reach $€ 162$ million in 2019 (Kienast, 2019).

Despite and also thanks to these changes in the consumption of advertising and the use of electronic devices, TV advertising can still be very efficient compared to other forms of advertising (Roozen and Meulders, 2015). Consumers who watch a TV spot tend to search online to find more information. It has been confirmed by revealing the existence of a significant correlation between TV advertising and the tendency for consumers to search for keywords (Joo et al., 2014, 2016). It has been shown that searching for additional information is sometimes directly induced by advertisements (R. Y. Du et al., 2019). Similarly, research has also shown how TV advertising affects the activity on other online channels, such as conversations on social media (Spotts et al., 2014).

Consumers can do online searches either in parallel or after advertising has been displayed, or even later. Searching begins naturally on the device that the consumer uses in parallel while watching TV. At this moment, it is crucial to realise the importance of being featured at the top of search results so that the consumers' attention is not lost. The website of a product or company should be displayed in top positions in online searches for the keywords that the consumer enters in a search engine. This principle of search visibility being the centre of modern marketing, connecting different communication channels in time and directly affecting its long-term sustainability, has been designated as search-centric marketing (Miklosik, 2016).

Methodology and research methods. Understanding correlations among native advertising, consumer interests, consumer searches, searches on various devices, and product sales is of utmost importance for designing an optimal customer journey. For example, it is vital to find out which advertisements trigger conversions, which keywords affect acquisitions, which channels should be attracted to reach target customers, what an online channel's incremental value is, what a mobile channel's additional influence is, etc.

The existing research on Generation $Y$ and $Z$ consumers has revealed valuable insights into their thinking and consumer decision-making. Although consumers do not prefer watching traditional TV, their following-up actions after the consumption of TV advertisements are not predictable. The paper, therefore, focuses on understanding whether and in what way Generation $Y$ and $Z$ members consume and responds to TV advertising. It seeks to find out in what way these users proceed in case they feel interested in TV advertising and whether one can assume that traditional advertising will continue to have an impact on the consumer decision-making of these generations as well.

The main objective of this paper is thus to determine whether and how young Slovak consumers on the verge of Generations $Y$ and $Z$ respond to TV advertising. To answer this complex question, the following research questions have been defined:

RQ1: Do young Slovak consumers on the verge of Generations $Y$, and $Z$ watch television and TV advertisements?

RQ2: How can TV advertisers capture their attention?

$\mathrm{RQ3}$ : What are the triggers of the follow-up information search?

$\mathrm{RQ4}$ : What devices and channels are attracting to find out more about the product?

RQ5: How do young Slovak consumers behave when searching online?

Finding answers to these research questions can help researchers and practitioners understand the thinking and behaviour of these young consumers regarding their response to TV advertisements. Thanks to this knowledge, communication campaigns that include TV can be designed in a way that supports the efficient delivery of the communication message and thus, the sustainability of marketing communication and the whole business. 
A., Miklosik, P., Starchon, D., Vokounova, M., Korcokova. The Future of TV Advertising Targeting Young Slovak Consumers

Since quantitative research is appropriate to explore behaviour (Aaker et al., 2014), this paper employs this approach to examine the behaviour of a target group when searching for additional information online.

The description of behaviour usually includes five essential components, namely: What, Who, When, Where, and How (lacobucci and Churchill, 2018). Figure 1 shows the research model that was used in this study, supplemented with an additional component "Why" as it was a focal point in consumer behaviour research.

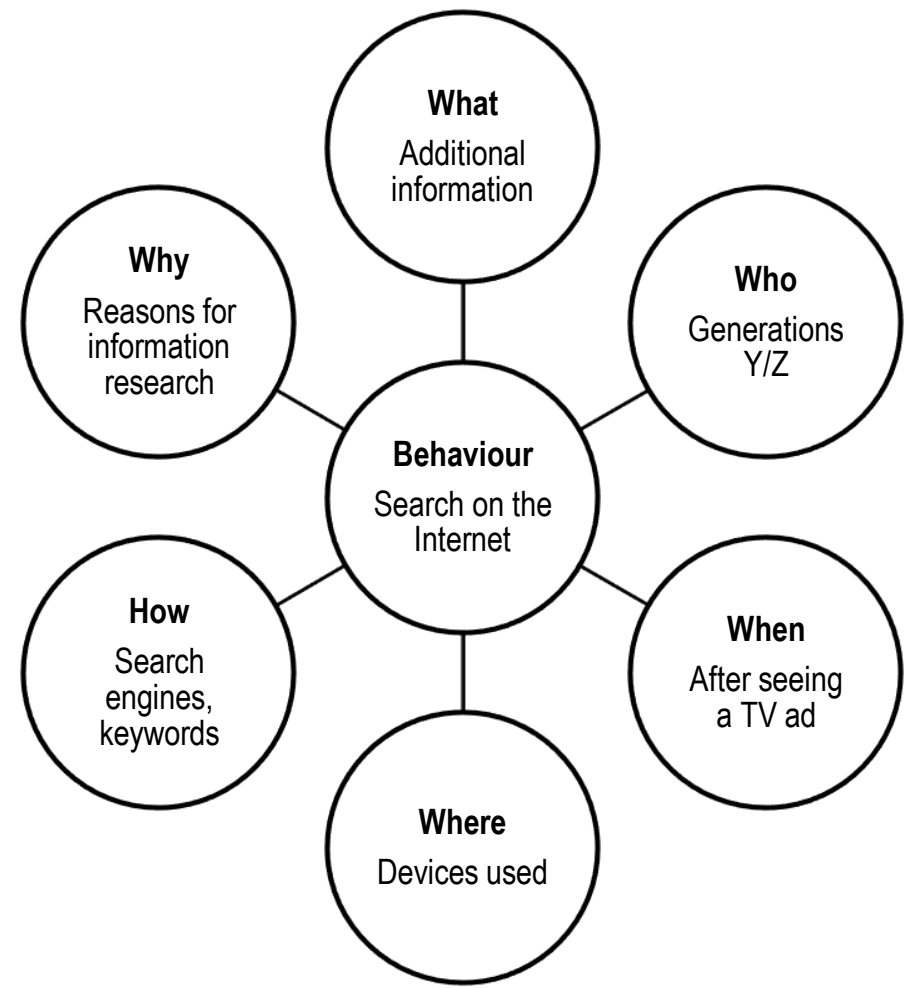

Figure 1. Research model

Sources: developed by the authors based on (lacobucci and Churchill, 2018)

To select a sample, we used non-probability sampling, which involves personal judgement somewhere in the selection process (lacobucci and Churchill, 2018). While statisticians prefer to avoid non-probability sampling designs, the latter is often used to legitimately and effectively (Aaker et al., 2014). The non-probability sampling method used in this study was judgmental and convenience sampling. The critical feature of judgmental sampling is that population elements are intentionally selected, sampling those who can offer some perspective on the research (lacobucci and Churchill, 2018). The results in specific individuals having a lower degree of probability of being selected into a sample than others. The convenience sampling used to obtain information quickly and inexpensively. Thus, the results of this exploratory study cannot be attributed to the whole Slovakian population born between 1990 and 1998.

The sample size should be appropriate for the analysis that is planned. If descriptive statistics are to be used, e. g. frequencies, then nearly any sample size will suffice (Israel, 2017). Sudman (1976) states 
A., Miklosik, P., Starchon, D., Vokounova, M., Korcokova. The Future of TV Advertising Targeting Young Slovak Consumers

that in the case of classification of the sample under review, each major group that is to be analysed should have a minimum sample size of 100 . Similarly, for each minor group, an example of 20 to 50 elements is needed. Our sample consisted of 135 people, with women representing $68.1 \%$. If Generation $Y$ is understood broadly (i.e., following the definition of being born between 1980 and 2000), all respondents could have been assigned to this generation as they all were born in 1998 and earlier. If Generation $Y$ is understood narrowly, one can say that a part of the respondents also belonged to generation Z. 53.3\% of the respondents were born in 1996-1998 and the remaining 46.7\% in 1995 and earlier.

The questionnaire was divided into two parts. The first part focuses on what young people do when they feel interested in a TV advertisement. They were asked to recall an ad that had captured their attention, trying to remember the reasons they had been involved and the whole process of adding information searching. It means where they searched for additional information, what devices they used to search, what keywords they inserted, how much time they dedicated to searching, and whether they bought the product they searched for. The second part of the questionnaire focused on the general process of searching for information online. Respondents were asked what devices they use to search for information, what the frequency of their searches is, what search engines they use, what they do if search results are not satisfying, and why.

The data collection took place between 25 April to 31 May 2019 by way of CAWI (convenience sampling), using Google services. The young people belonging to Generations $Y$ and $Z$ were the target group. Since the main topic was searching for information online, it was assumed that university students were the most suitable for this study due to their age and skills in using modern technologies (judgemental sampling). The approached students were from three Slovak universities, namely: The Faculty of Commerce of the University of Economics in Bratislava, the Faculty of Management of Comenius University in Bratislava, and the Faculty of Mass Media Communication at the University of Ss. Cyril and Methodius in Trnava.

Chi-squared test and t-test were performed to confirm the existence of statistically significant differences between different data categories. Pairwise using of comparisons allow comparing the averages, calculating the average ranking of answers for those respondents who commented on both groups at the same time. ANOVA analysis could not be applied to determine if there are differences between men and women in terms of devices used to search for additional information, due to data not having a normal distribution. Thus, the Kruskal-Wallis test was selected for further analysis.

Results. The first questions focused on TV watching and the factors behind being caught by advertising. Almost half of the young people (47.4\%) watch TV several times a week (Table 1). One-third of them watch TV rarely or never (33.4\%). The following question, asking whether they use a service that enables TV programs to be observed without advertisements, was only answered by those who watch TV at least occasionally, $\mathrm{n}=119$.

Table 1. Frequency of TV watching

\begin{tabular}{cc}
\hline Response & $\%$ \\
\hline Every day/almost every day & 24.4 \\
Several times a week & 23.0 \\
Several times a month & 19.3 \\
Less often & 21.5 \\
Never & 11.9 \\
\hline
\end{tabular}

Sources: developed by the authors. 
A., Miklosik, P., Starchon, D., Vokounova, M., Korcokova. The Future of TV Advertising Targeting Young Slovak Consumers

More than half of young people always watch TV with advertisements and almost one-fifth of them only occasionally without ads (Table 2).

All respondents were asked to recall a TV advertisement that captured their attention. We sought to identify the factors that had an impact on them has been interested in the ad.

Table 2. Watching TV without advertisements

\begin{tabular}{cc}
\hline Response & $\%$ \\
\hline Always without advertisements & 6.7 \\
Mostly without advertisements & 19.3 \\
Only occasionally without advertisements & 17.6 \\
Always with advertisements & 56.3 \\
\hline
\end{tabular}

Sources: developed by the authors.

Humour is the most significant factor behind being caught by a specific advertisement for two-thirds of the respondents (Table 3). A [2 test showed that men (74.4\%) are interested in humour more than women $(57.6 \%)$. Less than half of the respondents are attracted to an exciting story. If the young viewer is engaged in a specific product in a particular period, then he or she is naturally more sensitive towards messages and information about that product. Advertisements in this way captured more than a third of the respondents.

Table 3. The factor behind being caught by TV advertising

\begin{tabular}{cc}
\hline Response & $\%$ \\
\hline Humour & 63.0 \\
Interesting story & 43.7 \\
I was interested in the product & 36.3 \\
It was shocking & 17.8 \\
It featured a person that I admire & 11.9 \\
\hline
\end{tabular}

Sources: developed by the authors.

The next task was to recall a TV advertisement that led them to search for additional information. Two respondents never sought for further information. More than half of the others searched for additional information, especially to learn more about the product's characteristics and price (Table 4). One-third of them wanted to compare the brand with the competition and almost a quarter of them wanted to know the place the product can be purchased.

Table 4. Reasons for searching for additional information

\begin{tabular}{cccc}
\hline Response & $\%$ & Response & $\%$ \\
\hline Information about the & 59.3 & To compare the product with the & 32.6 \\
product's characteristics & competition & To find the place, it could be purchased at & 23.7 \\
To find out about the price & 53.3 & To
\end{tabular}

Sources: developed by the authors.

We were interested in knowing whether they searched for additional information online and what devices they used to do that. Most of them did search for additional information online $(89.6 \%)$. We asked these respondents $(n=121)$ to describe the whole process of searching for information online concerning the advertisement that captured their attention. To search for information, they used mostly their smartphone and more than half of them also their notebook (Table 5). 
A., Miklosik, P., Starchon, D., Vokounova, M., Korcokova. The Future of TV Advertising Targeting Young Slovak Consumers

Table 5. Devices used to search for additional information about the advertisement online

\begin{tabular}{cccc}
\hline Response & $\%$ & Response & $\%$ \\
\hline Smartphone & 85.9 & PC & 17.0 \\
Notebook & 56.3 & Tablet & 7.4 \\
\hline
\end{tabular}

Sources: developed by the authors.

Next, the average usage order for each device was calculated (Table 6). The order of the methods, according to the computed averages, confirms the law according to the frequency of responses. The mobile phone is used at first, followed by notebook and PC, with the tablet being last with the purpose to look for additional information.

Table 6. The overall average order of the devices used to find information related to advertising

\begin{tabular}{cccc}
\hline Response & Average order & Response & Average order \\
\hline Smartphone & 1.2 & PC & 2.87 \\
Notebook & 2.0 & Tablet & 3.15 \\
\hline
\end{tabular}

Sources: developed by the authors.

By pairing (each device with each), the t-test assisted in determining whether there were significant differences between the devices in the average order in which they were used to find additional information related to the advertisement. The results of the t-test confirmed that there is a significant difference $(p=0.00)$ between all pairs of devices compared (except for a couple of desktop PC and tablet). Thus, it could be concluded that firstly the respondents use mobile phones, notebooks second, and PCs or tablets third.

More than a half $(60.7 \%)$ used more than one device to search, with smartphones dominating as the most commonly used device $(51.1 \%)$ and notebooks as the second most frequently used device $(48.8 \%)$ (Figure 2).

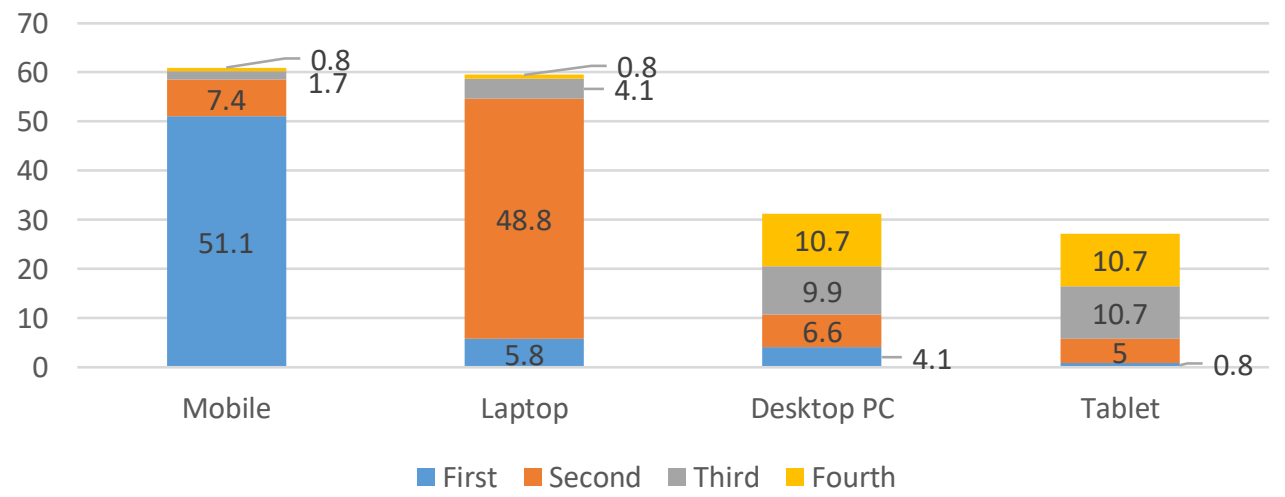

Figure 2. Ranking of the devices most commonly used to search for additional information about Sources: developed by the authors. the advertisement 
A., Miklosik, P., Starchon, D., Vokounova, M., Korcokova. The Future of TV Advertising Targeting Young Slovak Consumers

The Kruskal-Wallis test has revealed that no significant differences exist in the ranking of these devices when used by men and women to search for information related to the TV advertisement.

Almost one-third of the respondents spent 10 and 15 minutes, respectively, and one-fifth of them no more than 5 minutes searching for additional information (Table 7). It means that the vast majority of the young people dedicated no more than 15 minutes to search for further details. The main reason why they did not spend more than that searching was that they found what they were looking for or else it was not very important.

Table 7. Devices used to search for additional information about the advertisement online

\begin{tabular}{cccc}
\hline Search time & $\%$ & $n=97$ & $\%$ \\
\hline Total of max. 15 minutes & 80.2 & Reasons why they did not search for longer & \\
& & they found what they were looking for & 57.7 \\
Up to 5 minutes & 20.7 & it was not important & 43.3 \\
Up to 10 minutes & 31.4 & $n=24$ \\
Up to 15 minutes & 28.1 & they got discouraged by not seeing it immediately & 11.3 \\
\hline Total of min. 15 minutes & 19.8 & Reasons why they searched for longer & \\
& & I was interested in it & 58.3 \\
Up to a half an hour & 15.7 & I learnt something new searching & 41.7 \\
Up to an hour & 4.1 & I needed it & 33.3 \\
More than an hour & 0.0 & I did not mind spending so much time on it & 20.8 \\
\hline
\end{tabular}

Sources: developed by the authors.

One-fifth of the respondents dedicate at least 15 minutes but no more than an hour to searching. The main reason for the more prolonged search was that they became interested in the issue and learnt new information searching. When searching, the most commonly entered keyword was the name of a product or company (Table 8).

Table 8. The way keywords are entered

\begin{tabular}{cc}
\hline Response & $\%$ \\
\hline Name of the product/company & 92.6 \\
Type of product & 32.2 \\
Keywords from the slogan & 19.0 \\
«Price» was part of the keyword & 9.1 \\
"Location» was part of the keyword & 3.3 \\
\hline
\end{tabular}

Sources: developed by the authors.

Two-thirds of the respondents immediately found enough information and the company/brand was instantly visible $(67.8 \%)$. The others, too, found what they needed but only after several attempts. Almost half of them (Table 9) finally did not purchase the product, two-fifths purchased it, and the rest bought the product but from the competition.

The last part of the survey, again answered by all respondents, focused on the general process of searching for information online. Among the used devices, smartphone once again dominates, followed by notebook (Figure 3). 
A., Miklosik, P., Starchon, D., Vokounova, M., Korcokova. The Future of TV Advertising Targeting Young Slovak Consumers

Table 9. Consumer decision

\begin{tabular}{cc}
\hline Response & $\%$ \\
\hline Did not purchase the product & 48.8 \\
Purchased the product online & 23.1 \\
Purchased the product in a brick-and-mortar store & 17.4 \\
Purchased the product online from the competition & 8.3 \\
Purchased the product in a brick-and-mortar store from the competition & 2.5 \\
\hline
\end{tabular}

Sources: developed by the authors.

When searching for additional information, the vast majority of the respondents almost always uses their smartphone. On the other hand, the notebook is used by a quarter and often by half of them.

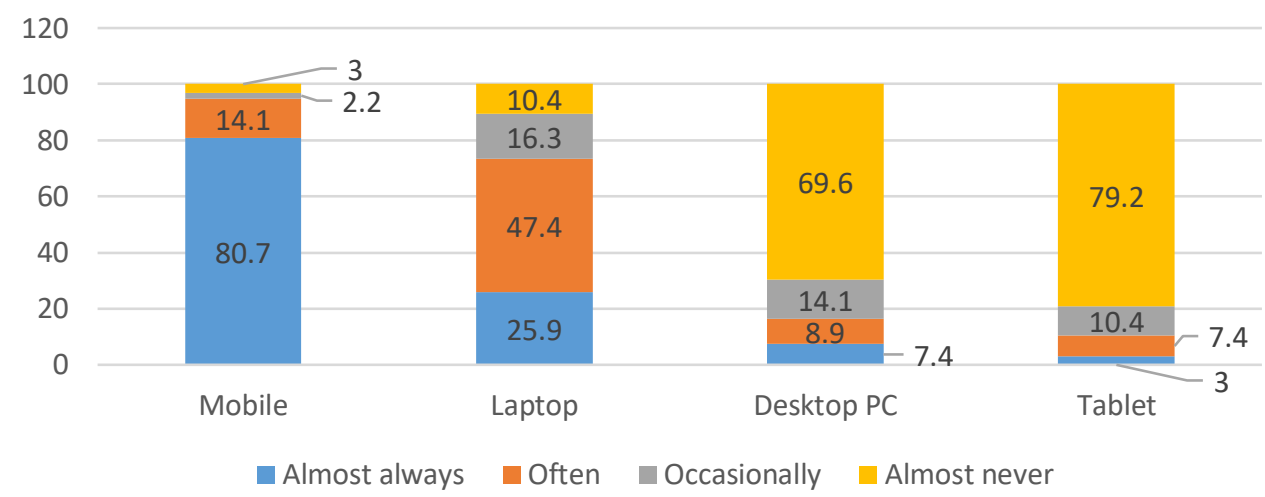

Figure 3. Frequency of using devices for searching

Sources: developed by the authors.

While the smartphone is the No. 1 choice for a vast majority, the notebook is choice No. 2 (Figure 4).

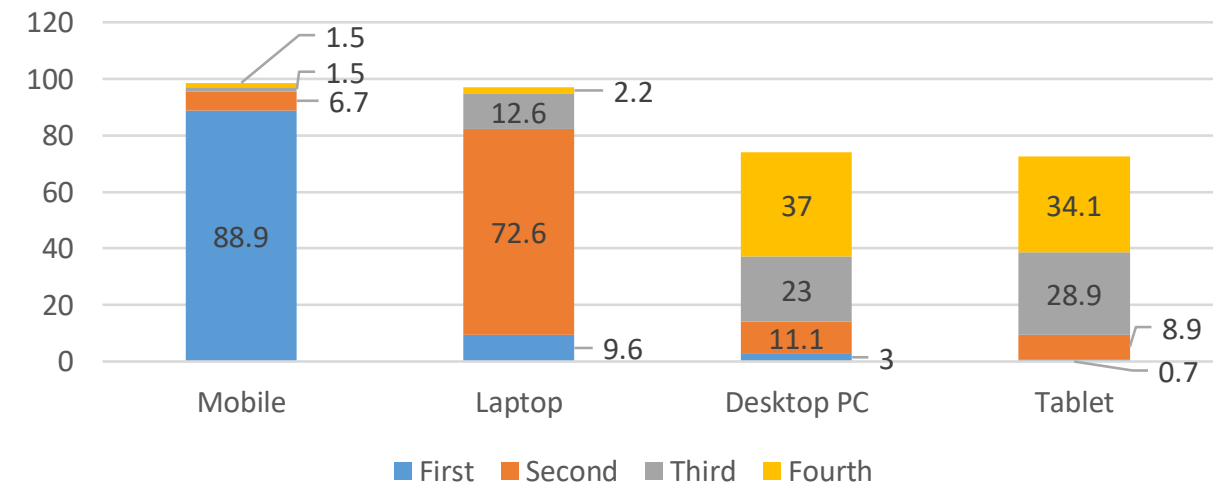

Figure 4. Ranking of the devices most commonly used to search for additional information online

Sources: developed by the authors. 
A., Miklosik, P., Starchon, D., Vokounova, M., Korcokova. The Future of TV Advertising Targeting Young Slovak Consumers

The Kruskal-Wallis test has revealed that no significant differences exist in the ranking of these devices when used by men and women to search for information online. Next, the average usage order for each device was calculated (Table 10). The order of the methods, according to the computed averages, confirms the law according to the frequency of responses. The mobile phone is used as the first device, followed by notebook, PC, and tablet, to search for additional information on the Internet.

Table 10. The overall average order of the devices used to find additional information online

\begin{tabular}{cccc}
\hline Response & Average order & Response & Average order \\
\hline Smartphone & 1.14 & PC & 3.27 \\
Notebook & 2.08 & Tablet & 3.33 \\
\hline
\end{tabular}

Sources: developed by the authors.

By pairing (each device with each), the t-test was applied to see if there were significant differences between the devices in the average order in which they were used to find additional information on the Internet. As a result of the t-test, there is a significant difference $(p=0.00)$ between all pairs of devices being compared (except for a couple of desktop PC and tablet). It can be confirmed that respondents use the mobile phone at the first, notebook second, followed by PC or tablet as a third device.

Almost all respondents (97\%) use Google as their search engine, three Safari (which is, in fact, Google by default), one Bing, and one Instagram. We asked them what they do if search results are not satisfying. After failing for the first time, most of the respondents do a new search with modified/new keywords, and a half of them also check the following pages of search results (Table 11).

Table 11. Procedure in case a search is not satisfying

\begin{tabular}{cc}
\hline Response & $\%$ \\
\hline I use different keywords & 75.6 \\
I check the following pages of search results & 50.4 \\
I give up & 5.9 \\
\hline
\end{tabular}

Sources: developed by the authors.

We were interested to learn how often they click on the following page(s) of search results. Most of them $(60 \%)$ do that rarely or never. A third of them do that often, and less than $10 \%$ almost always (Figure 5).

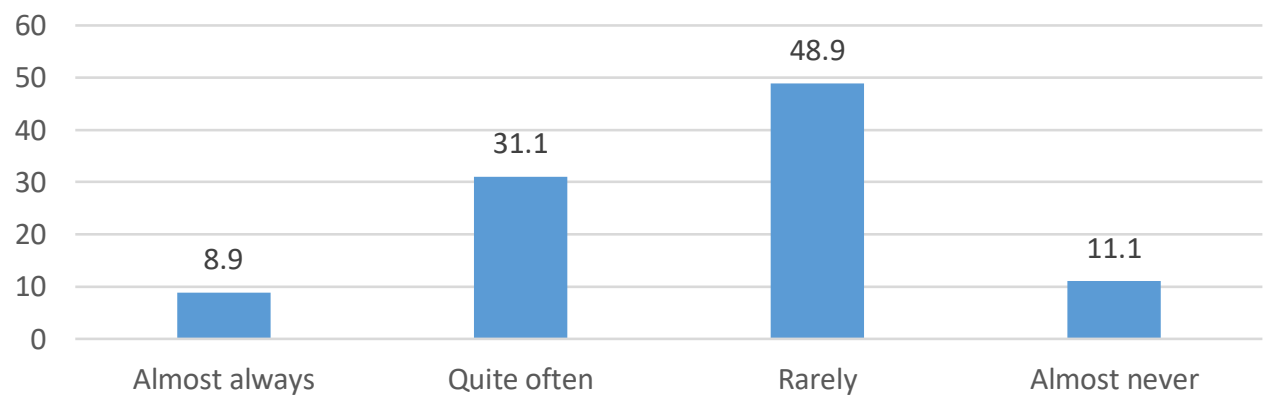

Figure 5. Checking the following pages of search results

Sources: developed by the authors. 
A., Miklosik, P., Starchon, D., Vokounova, M., Korcokova. The Future of TV Advertising Targeting Young Slovak Consumers

We asked those who almost always or quite often $(n=54)$ check the following pages with search results, why they do that, and the others $(n=81)$ why they do not do that. The main reasons given by those who tend to check also the following pages of search results are that they usually find there what they are searching for or they need it very much. The reason given by those who do not tend to check the following pages is that the information they are searching for is not going to be there anyway (Table 12).

Table 12. Reasons for (not) checking the following pages of search results

\begin{tabular}{|c|c|c|c|}
\hline Reasons for checking & $\%$ & Reasons for not checking & $\%$ \\
\hline$(n=54)$ & \multicolumn{3}{|c|}{$(n=81)$} \\
\hline I find it in the following pages & 57.4 & It will be faster if done differently & 50.6 \\
\hline \multirow{3}{*}{$\begin{array}{l}\text { I need it very much } \\
\text { Search results are not suitable even after } \\
\text { modifying the keywords }\end{array}$} & 53.7 & $\begin{array}{l}\text { It is not going to be on the next } \\
\text { page(s) anyway }\end{array}$ & 48.3 \\
\hline & 20.4 & I do not want to waste time & 37.0 \\
\hline & & Search results repeat themselves & 19.8 \\
\hline
\end{tabular}

Sources: developed by the authors.

Do they click on search results if the latter are labelled «Advertisement»? More than a third of the respondents consciously click on search results labelled «Advertisement». The others either try to avoid them or click on them by mistake (Table 13).

Table 13. Reasons for (not) checking the following pages of search results

\begin{tabular}{cccc}
\hline Response & $\%$ & Response & $\%$ \\
\hline Yes, if I see it is going to help me & 27.4 & No, I try to avoid them & 45.9 \\
Yes, I do not mind & 8.1 & I have not noticed such a label & 5.9 \\
Yes, but by mistake only & 12.6 & & \\
\hline
\end{tabular}

Sources: developed by the authors.

Young consumers born between 1990 and 1998, sometimes referred to as Generations Y and Z, still represent an impressive target group for TV advertisers. Despite the opportunities that modern technologies offer, young people often watch TV with advertisements. Almost half of them watch TV several times a week and, while watching TV, most of them do not use a service that enables the TV to be watched without advertisements (RQ1). Advertising ought to have especially humour or an interesting story (RQ2) to capture young people's attention.

If they search for additional information about a TV advertisement online, they mostly use their smartphone or notebook. The reason is that they want to learn more about the product (RQ3). They are willing to spend no more than 15 minutes making such a search. They only spend more time if they need to find searching for or if they learn the new information, they are interested in.

They use the name of the product, company or brand as their keywords. Half of them ultimately purchased the product they saw advertised on TV, while a fifth of them decided on a product offered by the competition. The smartphone is undoubtedly the No. 1 device, followed by the notebook. Except for a few of them, all use Google as their search engine (RQ4). If search results are not satisfying, they usually change the keywords, and a half of them also check the following pages with search results. However, the latter happens rather occasionally as they do not want to lose time, not trusting they are going to find the information there anyway. The label "Advertisement" next to a search result generally discourages them $(R Q 5)$. 
A., Miklosik, P., Starchon, D., Vokounova, M., Korcokova. The Future of TV Advertising Targeting Young Slovak Consumers

The results have revealed that, despite the theory indicating that TV advertising is becoming less effective with consumers of Generation $Z$, consumers on the verge of Generations $Y$ and $Z$ still respond to TV advertisements. It has been proven that, if it captures their attention, it can trigger further information research, often leading to a purchase decision. However, for a company/product to be considered in this process, it needs to be visible in search results. Almost $90 \%$ of consumers searched for information online, with Google representing the number one channel (not only the number one search engine) to start the information search. Thus, ensuring high visibility of the website/landing page in search results for a spectrum of keywords related to the product. Its features, pricing, place of sale and also competition is crucial for inclusion in the decision-making process, directly affecting the efficacy and sustainability of marketing communication and marketing strategy.

More than $80 \%$ of the searches start on a mobile device. Thus, the search visibility of the company and its products on mobile devices can be considered a priority before dealing with desktop search visibility. Information research that is triggered by a TV advertisement is quite short (less than 15 minutes in $80.2 \%$ of cases). Thus, despite young consumers being willing to repeat the search with different keywords or look to the second search engine results page in some cases, there is only a limited number of opportunities for a brand featured on TV to appear in search results and transform its presence from analogue to digital (or from TV to online). Most of the brands/products were visible immediately (67.8\%). However, the others were not there when the first search was conducted.

There are two main methodological limitations of this study that affect the applicability and generalisation of its results.

1. Lack of prior research studies on the topic - it was challenging to build up the literature review as there are not many papers published that would examine the consumption of TV advertisements by young consumers and their subsequent behaviours. Thus, the research gap defined is quite broad, and this paper can be considered as the first out of many focusing on providing more insights into the online search behaviour followed by the consumption of TV advertising.

2. Sample size - despite the attempt to make the sample size as significant as possible. Thus, quantitative research, sample sizes larger than 135 respondents should be. Therefore, the results of this exploratory study are not representative of the whole Slovakian population born between 1990 and 1998.

Using the labels Generation Y and Generation Z, although considered controversial by some, does not represent the foundation of this research and is only used to point out some of the common characteristics of these young consumers. The findings do not rely on using these labels and could be interpreted without reference to them. The research results offer valuable insights into the behaviour of young, digitally skilled consumers and therefore, the use of these labels is not considered as the limitation of this study.

Conclusions. TV advertising still has quite an impact on young consumers and, most importantly, it affects the purchasing behaviour leading to online and in-store purchases. There are more and more consumers who would avoid or ignore TV advertising. However, more than $50 \%$ of young consumers who recalled being affected by a TV spot decided to eventually buy a product, although more than $21 \%$ of these chose a competitor's brand. Thus, it can be concluded that TV advertising can still work if the advertisers understand that it no longer is necessary to get the message out. TV spots are triggering online information research starting by entering relevant keywords into a search engine. Only high search visibility on mobile devices can help the brand stay considered in the decision-making process. Otherwise, their television spots might as well be directly helping their competitors who have focused on the visibility of their products in full-text search results.

There are opportunities for follow-up research to reveal whether consumers from the other side of the age spectrum of Generation Z respond to TV ads at all and what their information research process 
looks likes. Are they trusting influencers so much that they would not even consider another brand in their purchasing decision-making process? Should companies only use TV advertising for products aimed at Generation $Y$ and older generations? Answering these and other questions, along with performing a comparison with different geographical markets, could bring additional insights into the topic of TV advertising and the behaviour of young consumers in this digital age.

Author Contributions: Conceptualisation, A. M., P. S., D. V., and M. K.; methodology, A. M., P. S., D. V., and M. K.; resources, A. M., P. S., D. V., and M. K.; data curation, A. M., P. S., D. V., and M. K.; writing - original draft preparation, A. M., P. S., D. V., and M. K.; writing - review and editing, A. M., P. S., D. V., and M. K.; visualisation, A. M., P. S., D. V., and M. K.; funding acquisition, A. M.

Funding: This research was funded by the grant scheme KEGA 016EU-4/2019 Innovative learning texts from marketing for secondary schools.

\section{References}

Aaker, D. A., Kumar, V., \& Day, G. S. (2014). Marketing Research. Wiley.

Chou, J. (2018). How Millennials are Marketing to Gen Z. Retrieved from https://www.entrepreneur.com/article/323383

Cordeiro, H. T. D., \& de Albuquerque, L. G. (2017). Career profiles of generation Y and their potential influencers. BAR - Brazilian Administration Review, 14(3). [Google Scholar] [CrossRef]

Dlacic, J., \& Kadic-Maglajlic, S. (2013). The role of gender and situational factors in wine consumption of Generation Y. South East European Journal of Economics and Business. [Google Scholar] [CrossRef]

Du, R. Y., Xu, L., \& Wilbur, K. C. (2019). Immediate Responses of Online Brand Search and Price Search to TV Ads. Journal of Marketing, 83(4), 81-100. [Google Scholar] [CrossRef]

Du, X., Dong, R., Li, W., Jia, Y., \& Chen, L. (2019). Online Reviews Matter: How Can Platforms Benefit from Online Reviews? Sustainability, 11(22). [Google Scholar] [CrossRef]

eMarketer. (2019). Time Spent with Mobile. Retrieved from https://www.emarketer.com/content/us-time-spent-with-mobile-2019

Gewald, H., Wang, X., Weeger, A., Raisinghani, M. S., Grant, G., Sanchez, O. P., \& Pittayachawan, S. (2017). Millennials' attitudes toward IT consumerisation in the workplace. Communications of the ACM, 60(10), 62-69. [Google Scholar] [CrossRef]

Gil-Pechuán, I., Palacios-Marqués, D., Peris-Ortiz, M., Vendrell, E., \& Ferri-Ramirez, C. (2014). Strategies in e-business. positioning and social networking in online markets (p. 165). Springer. [Google Scholar]

Google. (2012). The New Multi-Screen World Study - Understanding Cross-platform Consumer Behavior. In Think with Google. Retrieved from https://www.thinkwithgoogle.com/advertising-channels/mobile-marketing/the-new-multi-screen-world-study/

Greenberg, E., \& Kates, A. (2013). Strategic Digital Marketing: Top Digital Experts Share the Formula for Tangible Returns on Your Marketing Investment. McGraw-Hill Education.

Gurau, C. (2012). A life-stage analysis of consumer loyalty profile: comparing Generation X and Millennial consumers. Journal of Consumer Marketing, 103-113. [Google Scholar] [CrossRef]

Hall, A., Towers, N., \& Shaw, D. R. (2017). Understanding how Millennial shoppers decide what to buy: Digitally connected unseen journeys. International Journal of Retail \& Distribution Management, 45(5), 498-517. [Google Scholar] [CrossRef

Han, S., He, D., Yue, Z., \& Brusilovsky, P. (2015). Supporting Cross-Device Web Search with Social Navigation-Based Mobile Touch Interactions. 9146. [Google Scholar] [CrossRef]

Harms, B., Bijmolt, T. H. A., \& Hoekstra, J. C. (2017). Digital Native Advertising: Practitioner Perspectives and a Research Agenda. Journal of Interactive Advertising, 17(2), 80-91. [Google Scholar] [CrossRef]

Haviernikova, K., \& Kordos, M. (2019). Factors Affecting Innovative Activities of SMEs in Slovak Regions. In J. Horak (Ed.) Innovative Economic Symposium 2018 - Milestones and Trends of World Economy (IES2018) (Vol. 61). EDP SCIENCES. [Google Scholar] [CrossRef]

Herrando, C., Jimenez-Martinez, J., \& Martin-De Hoyos, M. J. (2019). Tell me your age and I tell you what you trust: the moderating effect of generations. Internet Research, 29(4), 799-817. [Google Scholar] [CrossRef]

Hitka, M., Paitinkova-Bartakova, G., Lorincova, S., Palus, H., Pinak, A., Lipoldova, M., Krahulcova, M., Slastanova, N., Gubiniova, K., \& Klaric, K. (2019). Sustainability in marketing through customer relationship management in a telecommunication company. Marketing and Management of Innovation, 4, 194-215. [Google Scholar] [CrossRef]

lacobucci, D., \& Churchill, G. A. (2018). Marketing research: Methodological foundations. CreateSpace Independent Publishing Platform.

Israel, G. D. (2017). Determining Sample Size. Retrieved from https://www.gjimt.ac.in/wp-content/uploads/2017/10/2 Glenn-D.Israel Determining-Sample-Size.pdf

Israfilzade K. (2018). "Y" generation engagement on consumer-generated media: differences between Lithuania and Azerbaijan. Intemational Joumal of Management, Accounting and Economics, 4(9), 962--979. [Google Scholar] 
A., Miklosik, P., Starchon, D., Vokounova, M., Korcokova. The Future of TV Advertising Targeting Young Slovak Consumers

Jepsen, A. L. (2007). Factors affecting consumer use of the Internet for information search. Journal of Interactive Marketing, 21(3), 21-34. [Google Scholar] [CrossRef]

Joo, M., Wilbur, K. C., Cowgill, B., \& Zhu, Y. (2014). Television Advertising and Online Search. Management Science, 60(1), 5673. [Google Scholar] [CrossRef]

Joo, M., Wilbur, K. C., \& Zhu, Y. (2016). Effects of TV advertising on keyword search. International Journal of Research in Marketing, 33(3), 508-523. [Google Scholar] [CrossRef]

Jun, S.-P., \& Park, D.-H. (2016). Consumer information search behavior and purchasing decisions: Empirical evidence from Korea. Technological Forecasting and Social Change, 107, 97-111. [Google Scholar] [CrossRef]

Kardes, F., Cronley, M., \& Cline, T. (2014). Consumer Behavior. Cengage Learning.

Kienast, K. (2019). Spending on advertising in the Slovak Republic from 2007 to 2019, by medium (in million euros). Retrieved from https://www.statista.com/statistics/491853/advertising-spend-by-medium-slovak-republic/

Kotov, A., Bennett, P. N., White, R. W., Dumais, S. T. \& Teevan, J. (2011). Modeling and analysis of cross-session search tasks. SIGIR'11 - Proceedings of the 34th International ACM SIGIR Conference on Research and Development in Information Retrieval. [Google Scholar] [CrossRef]

Lancaster, L. C., \& Stillman, D. (2009). When generations collide: how to solve the generational puzzle at work. Harper Collins.

Lizbetinova, L., \& Weberova, D. (2016). Managing attitudes of consumers towards brands and quality. Proceedings of the 27 th Intemational Business Information Management Association Conference - Innovation Management and Education Excellence Vision 2020: From Regional Development Sustainability to Global Economic Growth, IBIMA 2016, 2147-2156. [Google Scholar] Miklosik, A. (2016). Search-centric approach to sustainability of academic marketing. ECONOMIC ANNALS-XXI, 156(1-2), 92-96. [Google Scholar] [CrossRef]

Miklosik, A. (2014). Improving positions in search engines as the centre of consumer-oriented marketing campaings. Marketing Identity. Explosion of Innovations, 323-333. [Google Scholar]

Miklosik, A., Evans, N., Zak, S., \& Lipianska, J. (2019). A framework for constructing optimisation models to increase the visibility of organisations' information in search engines. Information Research-an International Electronic Journal, 24(1). [Google Scholar]

Montanez, G. D., White, R. W., \& Huang, X. (2014). Cross-Device Search. Proceedings of the 23rd ACM International Conference on Conference on Information and Knowledge Management, 1669-1678. [Google Scholar] [CrossRef]

Nadeem, W.. Andreini, D., Salo, J., \& Laukkanen, T. (2015). Engaging consumers online through websites and social media: A gender study of Italian Generation Y clothing consumers. International Joumal of Information Management, 35(4),432-442. [Google Scholar] [CrossRef]

Nielsen. (2015). Sceen Wars: The battle for eye spance in a TV-everywhere world. Retrieved from https://www.nielsen.com/us/en/insights/report/2015/screen-wars-the-battle-for-eye-space-in-a-tv-everywhere-world/

Okada, S. I., \& de Souza, E. M. (2011). Digital marketing strategies in the age of search. Revista Brasileira de Marketing, 10(1) 46-72. [CrossRef]

Olsavsky, F. (2016). Ethnocentrism of Slovak and Czech consumers - Generation approach. Proceedings of the 28th International Business Information Management Association Conference - Vision 2020: Innovation Management, Development Sustainability, and Competitive Economic Growth, 3458-3466. [Google Scholar]

Raman, P. (2019). Understanding female consumers' intention to shop online The role of trust, convenience and customer service. Asia Pacific Journal of Marketing and Logistics, 31(4), 1138-1160. [Google Scholar] [CrossRef]

Roozen, I., \& Meulders, M. (2015). Has TV advertising lost its effectiveness to other touch points? Communications-European Journal of Communication Research, 40(4), 447-470. [Google Scholar] [CrossRef]

Searle, B. (2019). Millennials, Gen X, Gen Z, baby boomers: how generation labels cloud issues of inequality. [Google Scholar] Smolka, S. (2019). Charakteristika generacii slovenskych spotrebitelov. Marketing Science and Inspirations, 14(1), 2-11. [Google Scholar]

Spotts, H. E., Purvis, S. C., \& Patnaik, S. (2014). How Digital Conversations Reinforce Super Bowl Advertising The Power of Earned Media Drives Television Engagement. Journal of Advertising Research, 54(4), 454-468. [Google Scholar][CrossRef] Statcounter. (2020). Search Engine Market Share Worldwide - December 2019. Retrieved from https://gs.statcounter.com/searchengine-market-share

Stefko, R., Bacik, R., Fedorko, R., Olearova, M., \& Rigelsky, M. (2019). Analysis of consumer preferences related to the use of digital devices in the e-commerce dimension. Entrepreneurship and Sustainability Issues. [Google Scholar] [CrossRef] Strategie. (2014). TNS Slovakia: Vlastníme viac ako 4 digitálne zariadenia. Retrieved from https://strategie.hnonline.sk/media/780801-tns-slovakia-vlastnime-viac-ako-4-digitalne-zariadenia Strzelecki, A. (2019). Google Web and Image Search Visibility Data for Online Store. Data, 4(3). [Google Scholar] [CrossRef] Strzelecki, A. (2020). Google Medical Update: Why Is the Search Engine Decreasing Visibility of Health and Medical Information Websites? International Journal of Environmental Research and Public Health, 17(4). [Google Scholar] [CrossRef] Sudman, S. (1976). Applied Sampling. Academic Press. [Google Scholar]

Tsai, M., \& Lin, Y. (2015). How the Usage of Mobile Multimedia Internet Devices Changes Internet TV Consumer Behaviors in Taiwan: Using PPS.tv (PPStream) as an Example. PICMET '15 Portland International Center for Management of Engineering and Technology, 1467-1476. [Google Scholar] [CrossRef]

Vilcekova, L. (2016). Media Credibility Perception Among Millennials in Slovakia. Journal of Marketing and Consumer Behaviour in 


\section{A., Miklosik, P., Starchon, D., Vokounova, M., Korcokova. The Future of TV Advertising Targeting Young Slovak}

Consumers

Emerging Markets. [Google Scholar] [CrossRef]

Vosen, S., \& Schmidt, T. (2011). Forecasting private consumption: survey-based indicators vs. Google trends. Journal of Forecasting, 30(6). [Google Scholar] [CrossRef]

Wang, H., Song, Y., Chang, M.-W., He, X., White, R. W., \& Chu, W. (2013). Learning to Extract Cross-session Search Tasks. Proceedings of the 22Nd International Conference on World Wide Web, 1353-1364. [Google Scholar] [CrossRef]

Wu, D., Dong, J., \& Tang, Y. (2018). Identifying and Modeling Information Resumption Behaviors in Cross-Device Search. ACM/SIGIR Proceedings 2018, 1189-1192. [Google Scholar] [CrossRef]

Андрій Міклошик,

Ph.D., доцент, Університет Коменського в Братиславі, Словацька республіка

Петро Штархов,

Ph.D., просресор, Університет Коменського в Братиславі, Словацька республіка

Дана Воконова,

Ph.D., Економічний університет в Братиславі, Словацька республіка

Маріна Корчокова,

Ph.D., Економічний університет в Братиславі, Словацька республіка

Дослідження впливу телевізійної реклами на молодь Словаччини

Основою успішної реалізації маркетингових стратегій $є$ аналіз поведінки споживачів та визначення факторів, які впливають на їх алгоритм пошук інформації та процесу прийняття рішень. У статті зазначено, що своєчасний моніторинг зміни споживчої поведінки у часі є першочерговим завданням для рекламних кампаній. У статті зазначено, що інтегровані програми маркетингових комунікацій повинні поєднувати традиційні та нові канали комунікацій (смартфони, телебачення та соціальні мережі тощо). При иьому авторами відмічено, що рівень сприйняття мультимедійного контенту та телевізійної реклами споживачами покоління Y та Z, значно відрізняються від попередніх поколінь. Таким чином, головною метою даного дослідження $є$ формування моделі споживчої поведінки молоді, у розрізі нових та традииійних каналів комунікації. Вихідні данні для дослідження сфоормовано на основі вибірки з 135 студентів університетів Словаччини. Емпіричне дослідження проведено з використанням шестикомпонентної моделі інтерпретації споживчої поведінки. У статті авторами емпірично підтверджено доцільність включення до комплексу комунікаційних інструментів традиційного каналу - телевізійної реклами, яка повинна бути орієнтована на молодь. У статті наголощено, що чим вище рівень популярності рекламних повідомлень у пошукових запитах молоді тим вищий рівень окупності рекламних інвестиції. Таким чином, інтегрована програма маркетингових комунікацій повинна забезпечувати топ-позиції у рейтингу за брендом, товаром та відповідними ключовими словами у пошукових системах. Так рівень видимості у пошукових системах безпосередньо впливає на ефективність маркетингової комунікаиії, сприяючи підвищенню ефективності бізнес діяльності. За результатами дослідження авторами виокремлено низку рекомендаиій щодо оптимізації комунікаційних кампаній, які містять телевізійну рекламу, орієнтовану на молодь.

Ключові слова: споживча поведінка, інформаційна діяльність, інтегровані маркетингові комунікації, пошукова видимість, телевізійна реклама, Словаччина.

Manuscript received: 28.02.2020

(C) The author(s) 2020. This article is published with open access at Sumy State University. 